\title{
Black African and Latino/a identity correlates with increased plasmablasts in MS
}

Kiel M. Telesford, PhD, Ulrike W. Kaunzner, MD, PhD, Jai Perumal, MD, Susan A. Gauthier, DO, MPH, Xian Wu, MPH, Ivan Diaz, PhD, Mason Kruse-Hoyer, MD, Casey Engel, BA, Melanie Marcille, BA, and Timothy Vartanian, MD, PhD

Neurol Neuroimmunol Neuroinflamm 2020;7:e634. doi:10.1212/NXI.0000000000000634
Correspondence

Dr. Telesford

kit2003@med.cornell.edu

or Dr. Vartanian

tiv2002@med.cornell.edu

\begin{abstract}
Objective

To determine the influence of self-reported Black African and Latin American identity on peripheral blood antibody-secreting cell (ASC) frequency in the context of relapsing-remitting MS.
\end{abstract}

\section{Methods}

In this cross-sectional study, we recruited 74 subjects with relapsing-remitting MS and 24 age-, and self-reported ethno-ancestral identity-matched healthy donors (HDs) to provide peripheral blood study samples. Subjects with MS were either off therapy at the time of study draw or on monthly natalizumab therapy infusions. Using flow cytometry, we assessed peripheral blood mononuclear cells for antibody-secreting B-cell subsets.

\section{Results}

When stratified by self-reported ethno-ancestry, we identified significantly elevated frequencies of circulating plasmablasts among individuals with MS identifying as Black African or Latin American relative to those of Caucasian ancestry. Ethno-ancestry-specific differences in ASC frequency were observed only among individuals with MS. By contrast, this differential was not observed among HDs. ASCs linked with poorer MS prognosis and active disease, including $\mathrm{IgM}^{+}$- and class-switched $\mathrm{CD} 138^{+}$subsets, were among those significantly increased.

\section{Conclusion}

The enhanced peripheral blood plasmablast signature revealed among Black African or Latin American subjects with MS points to distinct underlying mechanisms associated with MS immunopathogenesis. This dysregulation may contribute to the disease disparity experienced by patient populations of Black African or Latin American ethno-ancestry. 


\section{Glossary}

ASC = antibody-secreting cell; BALAwMS = Subjects with MS of Black African or Latin American self-identity; CAwMS = Subjects with MS of Caucasian self-identity; DMT = disease-modifying therapy; HD = healthy donors without MS; Ig = immunoglobulin; MSSS = MS Severity Scale Score; NAT = natalizumab therapy; PBMC = peripheral blood mononuclear cell; SLE = systemic lupus erythematosus; T25-FW = timed 25-foot walk.

Individuals with MS of Black African or Latin American selfidentity (BALAwMS) are more likely to experience a severe disease course compared with individuals with MS of Caucasian self-identity (CAwMS). ${ }^{1,2}$ Paraclinical measures of CNS inflammation (T2 lesion accumulation and lesion volume) may be pronounced, ${ }^{3,4}$ whereas atrophy metrics, including brain and retinal degeneration, appear accelerated among BALAwMS compared with CAwMS. ${ }^{5-7}$ Ethno-ancestry is clearly an important consideration in MS. Unfortunately, the paradox of ethno-ancestry being simultaneously relevant in MS yet underrepresented in both clinical and translational investigation is apparent both in clinical trials and observational research. We calculated an average of $2.7 \%$ of African Americans among total subjects enrolled in 7 clinical trials conducted between 2006 and $2017^{\mathrm{e}-\mathrm{e} 10}$ for which demographic data were available (table 1). Furthermore, there are essentially no reports providing direct biological evidence of potential mechanisms underlying ethno-ancestry-based clinical disparity. Retrospective chart review implicates the contribution of antibodysecreting cells (ASCs), highlighting a relationship between elevated intrathecal IgG among African American patients with MS relative to Caucasian patients ${ }^{8}$ and linking this differential to gray matter atrophy. ${ }^{9}$ Indeed, plasmablasts and plasma cells, as ASCs derived from antigen-experienced B cells, appear to be important drivers of both inflammatory ${ }^{10-12}$ and neurodegenerative aspects of MS pathogenesis. ${ }^{9,13,14}$ ASCs are enriched within the CSF during active gadolinium-enhancing disease, ${ }^{12}$
ASC-derived intrathecal IgG correlates with CNS atrophy, ${ }^{9}$ and IgM-producing ASCs are associated with aggressive disease course. $^{15, \mathrm{el1}}$ The present cross-sectional study therefore investigates whether the peripheral blood of subjects with MS identifying with ethno-ancestral categories more likely to exhibit poorer prognosis reflects an identity-based differential ASC signature.

\section{Methods}

\section{Standard protocol approvals, registrations, and patient consents}

All study subjects were recruited according to Weill Cornell Medicine Institutional Review Board-approved protocol \#1508016490R003. Subjects provided informed written consent at the Weill Cornell Medicine Multiple Sclerosis Center before study inclusion.

\section{Subject recruitment and study cohorts}

Study subjects represent a convenience sample comprising individuals with clinically definite MS according to the 2010 McDonald criteria and healthy donors without MS (HD). We recruited subjects on natalizumab therapy (NAT) as a primary study subject population. This enabled study recruitment from among a relatively accessible patient population. Furthermore, this facilitated our investigation of intact ASC biology (despite disease-modifying therapy) ${ }^{\text {e12 }}$

Table 1 Underrepresentation of individuals of Black African self-identity in Phase III clinical trials for relapsing MS in the last decade

\begin{tabular}{|c|c|c|c|}
\hline Clinical trial (year reported) & Total no. of subjects & No. (\%) of CA & No. $(\%)$ of BAA \\
\hline AFFIRM $^{\mathrm{e} 1}(2006)$ & 627 & $603(96)$ & $10(1.6)$ \\
\hline SENTINAL e2 (2006) & 1,171 & $1092(93)$ & $39(3.3)$ \\
\hline FREEDOMS ${ }^{\mathrm{e} 3}(2010)$ & 1,272 & Not reported & $77(6.1)$ \\
\hline TRANSFORMS $^{\mathrm{e} 4}(2010)$ & 1,292 & $1216(94.1)$ & Not reported \\
\hline TEMSO $^{\mathrm{e} 5}$ (2011) & 1,088 & $1058(97.3)$ & Not reported \\
\hline DEFINE $^{\mathrm{e} 6}$ (2012) & 1,234 & $969(78.5)$ & $26(2.1)$ \\
\hline CONFIRM $^{\mathrm{e7}}(2012)$ & 1,414 & $1191(84.1)$ & 27 (1.9) \\
\hline CARE MS I ${ }^{e 8}(2012)$ & 563 (IIT population) & $532(94.5)$ & Not reported \\
\hline CARE MS II ${ }^{\mathrm{e} 9}$ (2012) & 798 (IIT population) & 714 (89.5) & Not reported \\
\hline OPERA I/OPERA II ${ }^{\mathrm{e} 10}$ (2017) & 1,656 (IIT population) & Not reported & $72(4.3 \%)$ \\
\hline
\end{tabular}

Abbreviations: BAA = Black or African American self-identity; CA = Caucasian self-identity. 
inclusive of prospective pathogenic lymphocytes within the peripheral blood. MS NAT subjects required at least 3 prior doses for study inclusion. No subject had received lymphocytedepleting therapies at any point before study draw. Study subjects were asked to self-identify according to ethno-ancestral categories for subsequent stratification. Individuals identifying with "Black African" or "Latin American/Hispanic" ancestry were combined into a single cohort as groups (BALA) based on risk for greater disease severity ${ }^{2,16}$ relative to those identifying with "Caucasian/European ancestry" (CA). In addition to selfreported identity, we collected other demographic and clinical data for each cohort, including age (at study involvement), sex, disease duration, timed 25-foot walk (T25-FW), date since last clinical flare, and MS Severity Scale scores (MSSS).

\section{Sample collection, ASC frequency, and count determination}

We isolated peripheral blood mononuclear cells (PBMCs) through density-gradient Ficoll centrifugation. Ficoll-spun buffy coats were harvested within hours of peripheral blood draws and resuspended in volumes of standard staining buffer equal to the original whole blood. We stained cells according to a standard protocol using the following BioLegend antibodies: CD19 PE/Cy7 (clone HIB19), CD20 PerCP (clone 2H7), CD27 brilliant violet 421 (clone M-T271), CD38 APC(clone HIT2), CD138 PE (clone MI15), IgD APC/ Cy7(clone IA6-2), and IgM FITC (clone MHM-88). We performed flow cytometric analysis using a Becton Dickinson FACSVerse cytometer. We determined cell frequencies as the percent of a gated cell population among a parent cell population. Cell count was determined as the number of flow cytometry events within each defined analysis gate.

\section{Statistical analysis}

The primary outcomes of this study are percent frequency of total CD $19^{+}$ASCs, class-switched ASC subsets, and $\operatorname{IgM}^{+}$ASC subsets. In planning, the estimated sample size needed for a 2-sample means test was calculated based on preliminary data from natalizumab-treated subjects. Trends in the analysis for our additional study cohorts should be treated as exploratory in nature. Twenty-six subjects in each group were needed to detect a mean difference of 2 (SD: 2.5) in class-switched frequency between ethno-ancestral groups; 17 subjects in each group were needed to detect a mean difference of 1 (SD: 1$)$ in IgM $^{+}$ASC frequency, assuming alpha of 0.05 and power of 0.8 . We calculated summary statistics using frequencies and proportions for categorical variables and mean, SDs, medians, and interquartile ranges for continuous variables. Demographic and clinical characteristics were compared between ethno-ancestry groups using the 2-sample $t$ test, the Wilcoxon rank-sum test, or the Fisher exact test as appropriate. Bivariate analyses were used to determine the associations between age, sex, ethno-ancestry, MS disease status, MS disease duration, and outcome measures (i.e., percent frequency and absolute counts of total CD19 ${ }^{+}$ ASCs, class-switched ASC subsets, and $\operatorname{IgM}^{+}$ASC subsets) using simple linear regression or 2-sample $t$ test. We further constructed multivariable linear regression models to assess the associations between ethno-ancestry and outcome measures after adjusting for a priori hypothesized confounders age, sex, and MS disease duration. To assess the potential interaction (i.e., effect-measure modification) between ethnoancestry and disease status in relation to outcome measures, we performed subgroup analyses for HD subjects and subjects with MS separately. All statistical tests were 2 sided, with a significance level of $p<0.05$. All analyses were conducted with SAS version 9.4 (SAS Institute, Inc, Cary, NC).

\section{Data availability}

Anonymized data not shown will be shared by request from a qualified investigator.

\section{Results}

\section{Demographic and clinical characteristics}

We enrolled a total of 54 subjects on natalizumab ("NAT"; 27 BALAwMS, 27 CAwMS), 20 subjects who were off drug at the time of study draw ("no disease-modifying drug [DMT]”; 12 BALAwMS, 8 CAwMS), and 24 HD subjects who lacked an MS diagnosis ("HD"; 11 BALA HD, 13 CA $\mathrm{HD}$ ). Subjects were comparable in age, both within and between cohorts, whereas sex ratio varied. BALAwMS subjects exhibited a longer on average disease duration compared with CAwMS subjects, with this difference more pronounced in the no-DMT cohort (table 2) Clinically, there was some (albeit, nonsignificant) indication of greater acute disease activity and disability within BALAwMS compared with CAwMS subjects at the time of the draw. Thus, MSSS scores were greater, and T25-FW measures longer, among BALAwMS compared with CAwMS subjects in both NAT and no-DMT groups. Of these measures, only T25-FW in the NAT cohort reached statistical significance. Among our no-DMT cohort, BALAwMS subjects exhibited on average a shorter period since their last acute relapse than CAwMS. This was paralleled by a commensurate measure of months since previous high-dose steroid administration. The majority of subjects with MS in our study did not possess comorbidities. However, there were several reported autoimmune, rheumatoid, or oncologic indications: CAwMS NAT_eczema, mononucleosis, asthma, fibromyalgia, celiac disease, Graves disease, and malignant thyroid neoplasm; BALAwMS NAT — thyroid (diffuse goiter), asthma, irritable bowel syndrome, pituitary microadenoma, and positive antinuclear antibodies; CAwMS no DMT-ulcerative colitis, irritable bowel syndrome, hypothyroidism, and psoriasis; and BALAwMS no DMT—-positive antinuclear antibodies.

\section{Subjects with MS of Black African or Latin American ethno-ancestral identity exhibit enhanced ASC frequencies over those of Caucasian identity}

To test our hypothesis that stratifying our study sample according to ethno-ancestral cohorts at risk of severe disease (BALAwMS relative to CAwMS) would reveal a differential ASC frequency within the peripheral blood compartment, we first interrogated the PBMCs of subjects with MS on 
Table 2 Demographic and clinical characteristics for patients with MS and HD study participants

\begin{tabular}{|c|c|c|c|c|c|c|c|c|c|}
\hline & \multicolumn{3}{|l|}{ MS NAT } & \multicolumn{3}{|l|}{ MS no DMT } & \multicolumn{3}{|l|}{ HD } \\
\hline & \multirow{2}{*}{$\frac{C A}{N=27}$} & \multirow{2}{*}{$\begin{array}{l}\text { BALA } \\
\mathrm{N}=27\end{array}$} & \multirow{2}{*}{$\begin{array}{l}p \\
\text { Value }\end{array}$} & \multirow{2}{*}{$\frac{C A}{N=8}$} & \multirow{2}{*}{$\frac{\text { BALA }}{\mathrm{N}=12}$} & \multirow{2}{*}{$\begin{array}{l}p \\
\text { Value }\end{array}$} & \multirow{2}{*}{$\frac{C A}{N=13}$} & \multirow{2}{*}{$\begin{array}{l}\text { BALA } \\
\mathrm{N}=11\end{array}$} & \multirow{2}{*}{$\begin{array}{l}p \\
\text { Value }\end{array}$} \\
\hline & & & & & & & & & \\
\hline Age, y & $35.37(11.86)$ & $32.63(9.12)$ & 0.35 & $34.88(6.10)$ & $37.17(6.66)$ & 0.45 & $\begin{array}{l}29.33 \\
(6.97)\end{array}$ & $\begin{array}{l}32.82 \\
(8.85)\end{array}$ & 0.30 \\
\hline Sex, no. (\%) & & & 0.1 & & & 0.17 & & & 0.36 \\
\hline Female & $21(77.8)$ & $26(96.3)$ & & $3(37.5)$ & $9(75.0)$ & & $2(15.4)$ & $4(36.4)$ & \\
\hline Male & $6(22.2)$ & $1(3.7)$ & & $5(62.5)$ & $3(25.0)$ & & $11(84.6)$ & $7(63.6)$ & \\
\hline $\begin{array}{l}\text { Disease duration, median (IQR), } \\
\text { mo }\end{array}$ & $62(26-106)$ & $99(45-148)$ & 0.23 & $3(0-70)$ & $56(13-132)$ & 0.12 & - & - & - \\
\hline MSSS, median (IQR) & $\begin{array}{l}0.49 \\
(0.23-2.60)\end{array}$ & $\begin{array}{l}1.92 \\
(0.23-4.79)\end{array}$ & 0.28 & $\begin{array}{l}1.16 \\
(0.89-2.64)\end{array}$ & $\begin{array}{l}1.86 \\
(0.59-5.90)\end{array}$ & 0.85 & - & - & - \\
\hline Undetermined values & 5 & 9 & & & & & - & - & - \\
\hline T25-FW, s & $3.70(0.49)$ & $4.29(0.55)$ & 0.009 & $3.85(1.06)$ & $5.30(1.92)$ & 0.35 & - & - & - \\
\hline Undetermined values & 11 & 17 & & 6 & 5 & & - & - & - \\
\hline $\begin{array}{l}\text { Days since last clinical flare, } \\
\text { median (IQR) }\end{array}$ & - & - & - & $\begin{array}{l}146 \\
(52.5-364.5)\end{array}$ & $\begin{array}{l}56 \\
(23-659)\end{array}$ & 0.90 & - & - & - \\
\hline $\begin{array}{l}\text { Months since high-dose steroids, } \\
\text { median (IQR) }\end{array}$ & - & - & - & $\begin{array}{l}8.80 \\
(4.20-73.85)\end{array}$ & $\begin{array}{l}3.30 \\
(1.60-11.00)\end{array}$ & 0.35 & - & - & - \\
\hline None & - & - & - & 4 & 3 & & - & - & - \\
\hline
\end{tabular}

Abbreviations: BALA = Black African or Latin American self-identity; CA = Caucasian self-identity; HD = healthy donors without MS; IQR = interquartile range; MSSS = MS Severity Scale Score; MS NAT = subjects with MS on natalizumab; MS no DMT = subjects with MS not on any disease-modifying therapy at the time of study participation; T25-FW = timed 25-foot walk.

Both demographic and clinical data were derived from chart review. Mean duration of MS is calculated from years since diagnosis to study draw. Data are given as mean (SD) except where indicated. The $p$ values displayed were derived from 2-sample $t$ test, Wilcoxon rank-sum test, or Fisher exact test. These were employed when comparing demographic and clinical characteristics between ethno-ancestry groups.

natalizumab. One of our most effective therapies, natalizumab, functions in MS by binding to the alpha-4 integrin subunit, essentially inhibiting the binding and trafficking of lymphocytes across the blood-brain barrier. In theory, this restricts otherwise pathogenic CNS-destined cells to the periphery.

ASCs represent a continuum of antigen-activated B cells that, through differentiation into plasmablasts and mature plasma cells, dedicate metabolic and protein processing mechanisms to antibody production. For this study, we use the term ASCs as inclusive of plasmablasts and maturing plasma cells found in the blood. Despite heterogeneity across the ASC spectrum, these cells may be collectively identified as brightly positive for $\mathrm{CD} 27$ and $\mathrm{CD} 38 .{ }^{17} \mathrm{We}$ have thus used this general definition to clarify the distinct total ASC population among blood-borne $\mathrm{CD} 19^{+}$cells. We found the majority of circulating ASCs to express high levels of HLA-DR (and CD86), (figure e-1, links.lww.com/NXI/ A158), consistent with recently generated plasmablast identity as shown by others. ${ }^{18}$ Also in agreement with others, the majority of circulating $\mathrm{CD} 27^{\mathrm{hi}} \mathrm{CD} 38^{+}$cells lack CD20 expression, whereas a substantial portion express $\mathrm{CD} 138$, possibly distinguishing these as apoptosis resistant, and perhaps bound for long-term residence in the bone marrow.

We uncovered a significant differential, with BALAwMS exhibiting on average a greater frequency of total ASCs compared with CAwMS (figure 1A). The majority of these ASCs were class-switched $\mathrm{IgD}^{-}$(figure $1, \mathrm{~B}$ and $\mathrm{D}$ left panel), with a smaller proportion of $\operatorname{IgM}^{+}$ASCs (figure $1, \mathrm{C}$ and $\mathrm{E}$ left panel). We further assessed $\mathrm{CD} 38^{+} \mathrm{CD} 138^{+}$subpopulations based on recent work, which implicates these ASCs as significant intrathecal contributors to inflammatory gadolinium-enhancing MS. ${ }^{12}$ Both class-switched and $\operatorname{IgM}^{+}$. $\mathrm{CD} 38^{+} \mathrm{CD} 138^{+}$ASCs were significantly enhanced among BALAwMS compared with CAwMS (figure 1, D and E, respectively, right panels). Our findings were similar after adjusting for age, sex, and disease duration (table e-1, links. lww.com/NXI/A159)

\section{Ethno-ancestry-based differential ASC} frequency is present among those with MS and not HDs

Although natalizumab possesses a targeted mechanism of action, we wished to examine our findings without its influence. To investigate the generalizability of our findings 
Figure 1 Subjects with MS self-identifying with Black African or Latin American ethno-ancestry exhibit heightened peripheral blood ASC frequencies

A

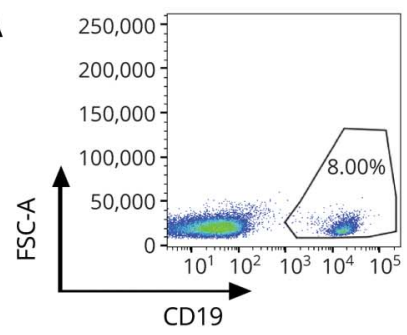

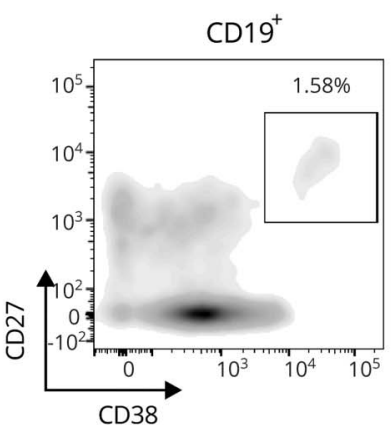
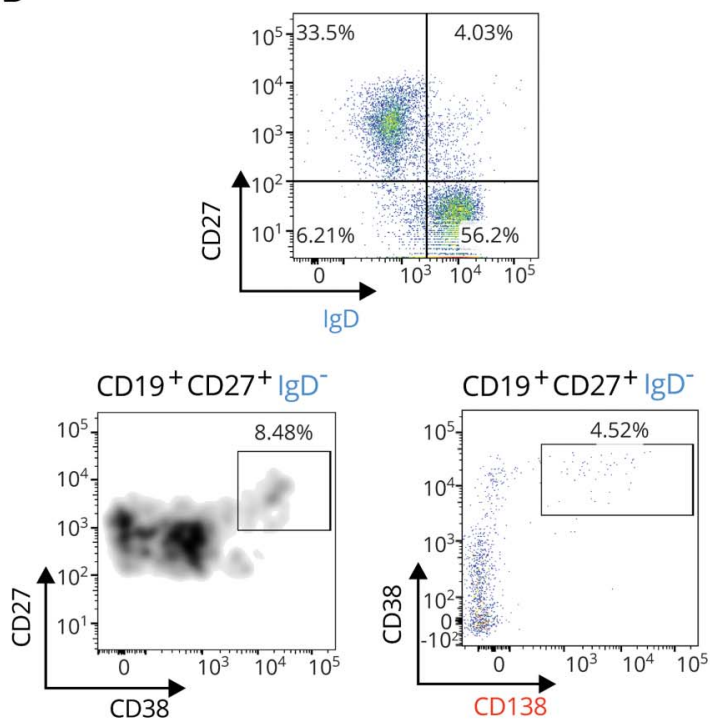

D

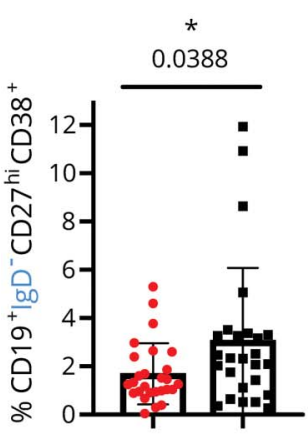

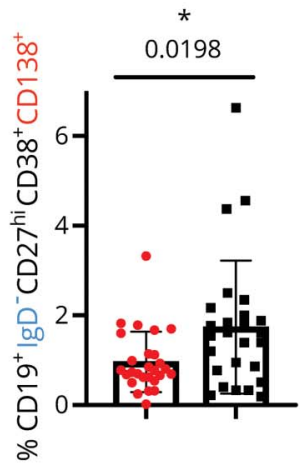

C
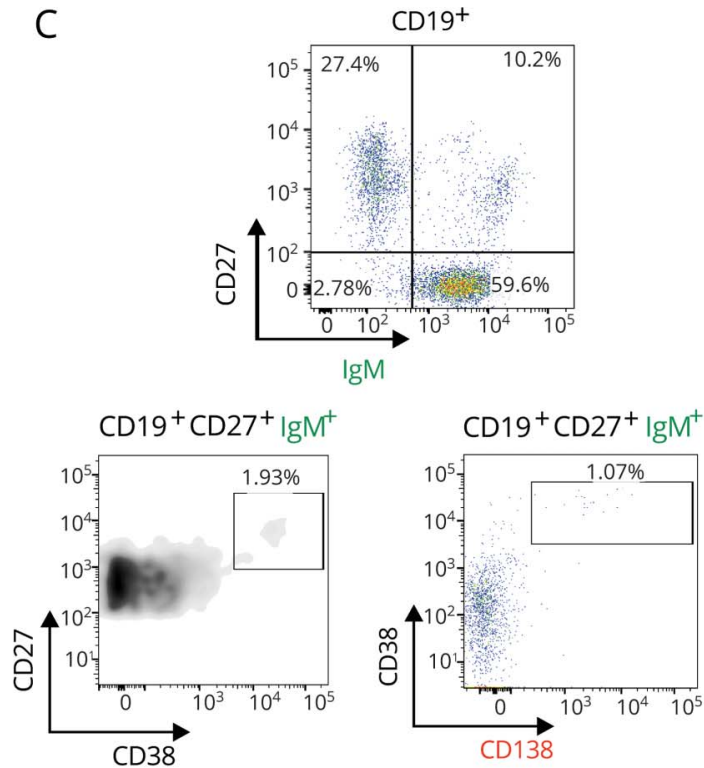

$\mathrm{E}$

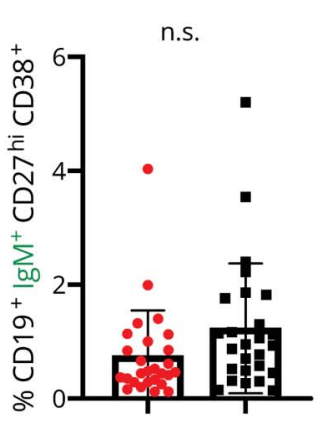

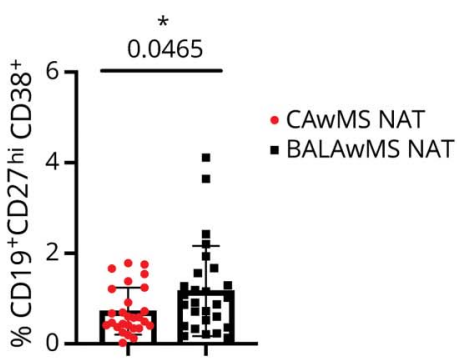

IgM

Peripheral blood samples from subjects with MS on natalizumab were stratified according to self-identified ethno-ancestry at risk of more severe MS, CAwMS $(n=27)$, and BALAwMS ( $n=27$ ). Percent frequency of different ASC populations was compared between these cohorts. (A) Representative gating strategy for ASCs; CD27 ${ }^{\text {hi }} C D 38^{+}$total ASCs were selected from $C D 19^{+}$cells for downstream phenotypic subset analysis. (B) Representative gates for class-switched lgD ${ }^{-}$ $\mathrm{CD}^{+} 7^{+}$total ASCs and CD38 ${ }^{+}$CD138 subpopulation. (C) Representative gates for $\mathrm{IgM}^{+} \mathrm{ASCs}$. (D and E), Average frequencies of previously described classswitched (D) and $\mathrm{IgM}^{+}$(E) ASC populations; error bars represent SD, $p$ values determined the by 2 -sided $t$ test. ASC = antibody-secreting cell; BALAwMS = subjects with MS of Black African or Latin American self-identity; CAwMS = subjects with MS of Caucasian self-identity; NAT = natalizumab therapy.

beyond the influence of natalizumab, and to examine whether our observations were present in individuals without MS, we extended MS subject enrollment to include those not on any established DMT. Among these subjects, approximately $60 \%$ were treatment-naive, having never been exposed to any DMT. Those with any previous 
exposure to therapy had been off of DMT for at least 2 months before study participation.

Our analysis of these cohorts demonstrated an ethnoancestry-dependent discrepancy in ASC frequency, with this difference present across essentially all ASC subsets found among natalizumab and off-treatment MS subjects (figure 2, A-C). To determine whether this ethnicitydependent difference was associated with MS, we performed the same phenotypic analysis among HDs. In stark contrast to our findings in subjects with MS, there was virtually no difference in ASC frequency found among HDs (figure 2, $\mathrm{A}, \mathrm{D}$, and $\mathrm{E}$ ).

\section{Class-switched ASCs are differentially enriched among subjects with MS of Black African or Latin American ethno-ancestral identity}

Frequencies of both class-switched and $\operatorname{IgM}^{+}$ASCs were significantly enhanced among subjects with MS of Black African or Latin American compared with Caucasian ethno-

Figure 2 Ethno-ancestry-based differences in ASC frequency are present among subjects with MS but not HDs

A

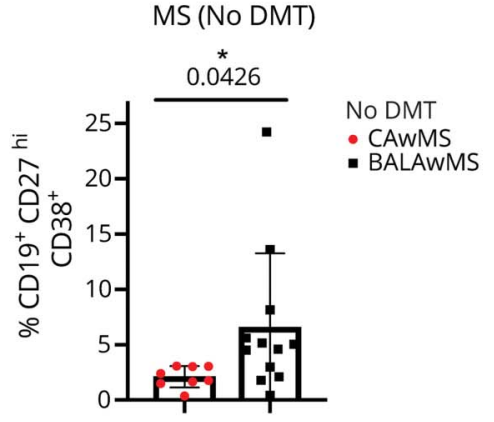

HD

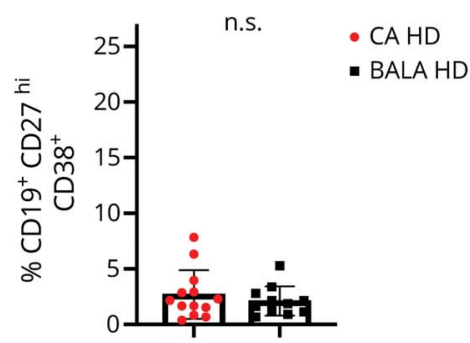

B

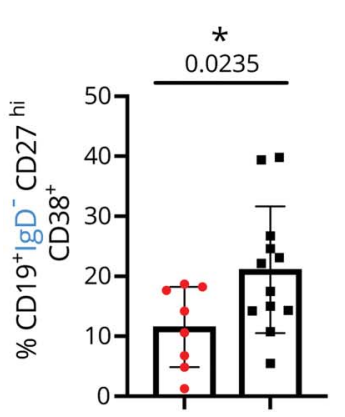

D

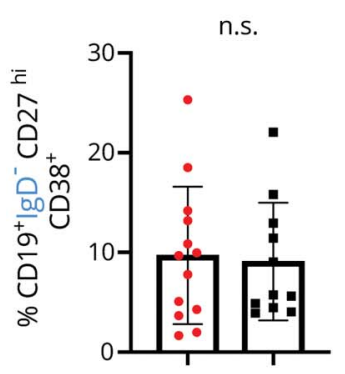

$H D$

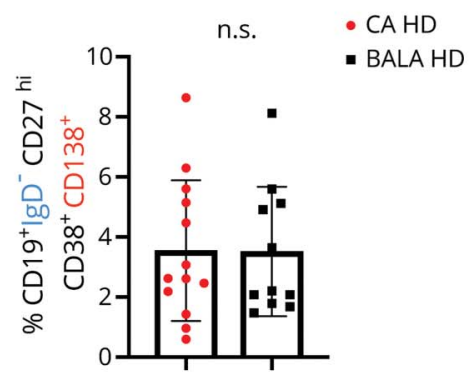

C

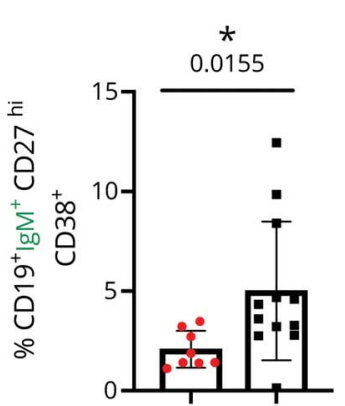

MS (No DMT)

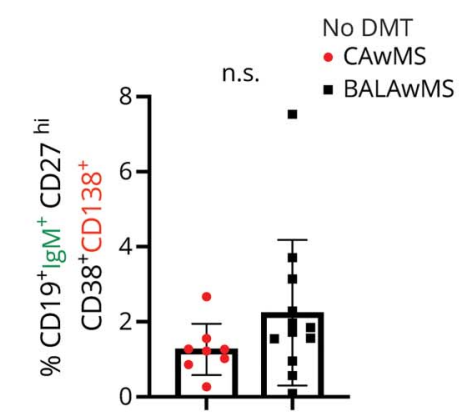

$\mathrm{E}$

HD
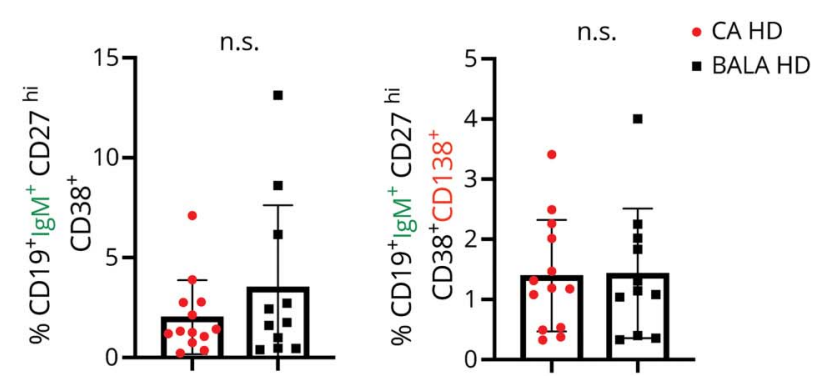

Average frequencies of previously described total $C D 19^{+}(A)$, class-switched $C D 19^{+} \mid \mathrm{gD}^{-}(\mathrm{B}$ and $\mathrm{D})$ and unswitched $C D 19^{+}$IgM ${ }^{+}(C$ and $E) \mathrm{ASC}$ populations. CAwMS $(n=8)$ and BALAwMS $(n=12) ;$ CAHD $(n=13)$ and BALAHD $(n=11)$. Error bars represent SD, $p$ values determined by the 2-sided $t$ test. ASC = antibodysecreting cell; BALA HD = healthy donors without MS of Black African or Latin American self-identity; BALAwMS = Subjects with MS of Black African or Latin American self-identity; CAwMS = Subjects with MS of Caucasian self-identity; CA HD = healthy donors without MS of Caucasian self-identity. 
ancestry. To ascertain whether these frequencies (representative of ASCs derived from precursor B cells) affected overall circulating numbers of these cells, we compared flow cytometry event counts of class-switched and IgM ASCs among our cohorts. In contrast to heightened frequency differences across both switched and unswitched classes in the context of MS, only class-switched (figure 3A) but not $\mathrm{IgM}^{+}$ASCs were differentially enriched in subjects of Black African or Latin American identity compared with those of Caucasian ethno-ancestry (figure 3B).

Taken together, our observations show an identity-dependent differential of ASC frequency in the context of MS, and support the existence of alternative underlying immunopathogenesis across different ethno-ancestries.

\section{Discussion}

The major finding of our investigation was the significant ethno-ancestry-based differential of peripheral blood ASC subsets examined among subjects with MS but not HD subjects. Both interventional and observational clinical studies reveal a clear pathogenic role for blood-borne, CNS-infiltrating B cells in MS. ${ }^{19-21}$ There appears to be crosstalk between the peripheral blood and CNS as demonstrated by clonal sequencing approaches. ${ }^{22,23}$ For instance, recent observations by Eggers et al. ${ }^{12}$ suggest that it is predominantly peripheral blood memory B cells and derived $\mathrm{CD} 138^{+}$plasma cells that are associated with CNS pathology during active inflammatory MS. Continued crosstalk between the blood and CNS may lead to an accumulation CNS-resident ASCs. Several lines of

Figure 3 Numbers of class-switched but not $\operatorname{lgM}^{+}$ASCs are elevated according to ethno-ancestry among subjects with MS

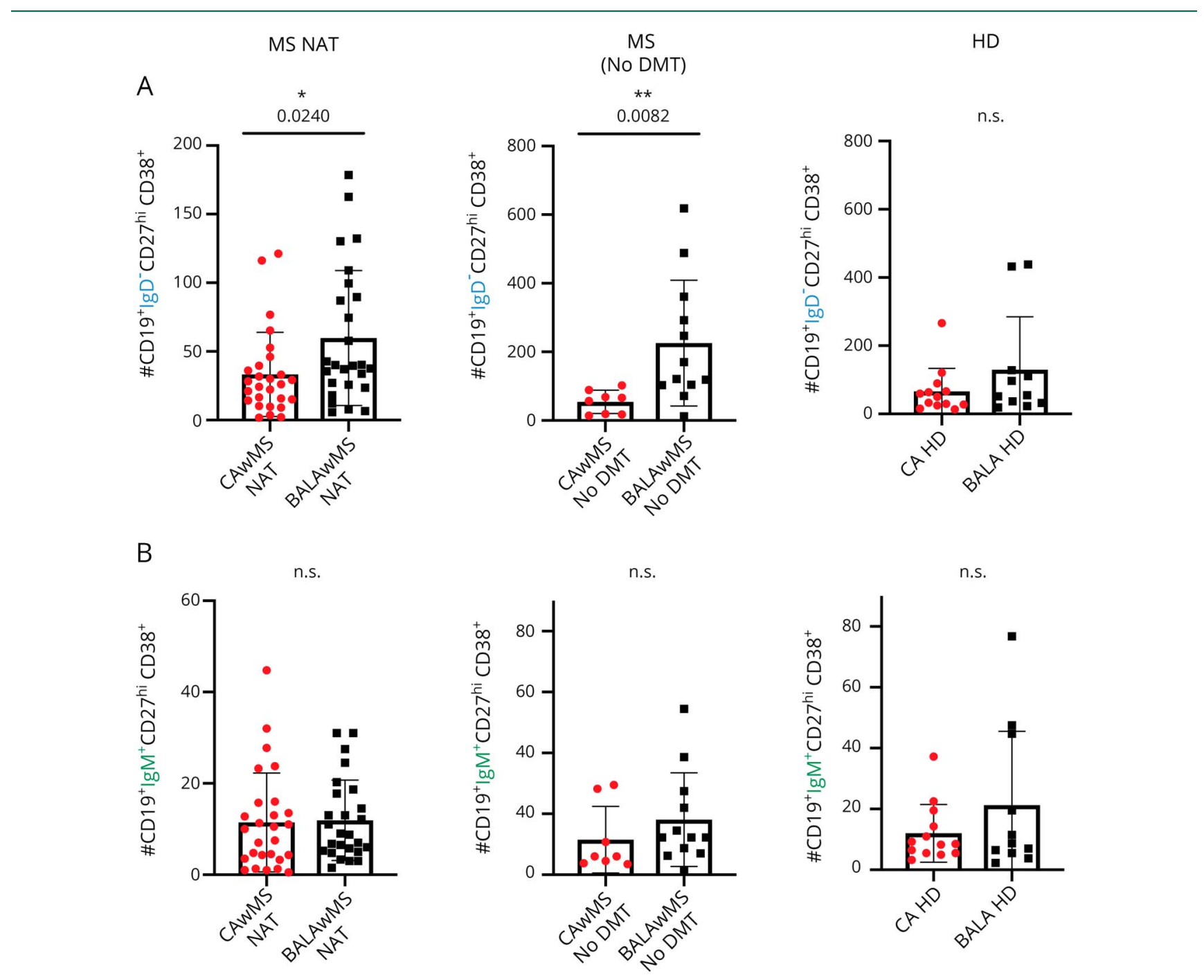

Average number of circulating ASCs for each subject cohort as obtained through event counts derived from flow cytometry gates described prior. Classswitched CD19 ${ }^{+}$IgD ${ }^{-}$ASCs (A); unswitched CD19 ${ }^{+}$IgM ${ }^{+}$ASCs (B). Error bars represent SD, $p$ values determined by the 2-sided $t$ test. ASC = antibody-secreting cell; BALA HD = healthy donors without MS of Black African or Latin American self-identity; BALAwMS = Subjects with MS of Black African or Latin American self-identity; CAwMS = Subjects with MS of Caucasian self-identity; CA HD = healthy donors without MS of Caucasian self-identity; NAT = natalizumab therapy. 
evidence point to a pernicious ectopic humoral response within CNS tissue, likely maintained by $\mathrm{CD} 138^{+}$apoptotic-resistant plasma cells. ${ }^{12,24, \mathrm{e} 13}$ These include the existence of pathogenic autoantibodies, ${ }^{13,14,25, \mathrm{e} 14}$ persistence of intrathecal antibodies despite peripheral $\mathrm{CD}_{20}{ }^{+}$memory B-cell depletion, ${ }^{26}$ and observations of follicle-like aggregates in progressive MS. ${ }^{27}$ Our study reveals remarkable trends consistent with, and additive to, previous observations that implicate differential intrathecal humoral responses in patients consistently shown to be at risk of aggressive manifestation of MS. ${ }^{8,9}$ We note that although our BALAwMS cohort exhibited an increased disease manifestation, this current study is not powered to assess the clinical differences. Nonetheless, having been conducted using peripheral blood, our work highlights the potential value of this accessible compartment for subsequent research into questions of ethno-ancestry and MS.

Taking into account data supporting a B cell-centric view of MS immunopathogenesis, and previous work showing enhanced intrathecal humoral responses among African Americans with MS, we suggest that among BALAwMS, CNS-infiltrating B cells may be more likely driven toward ASC differentiation. Our findings provide plausibility for this scenario, as ASC frequency used as the primary outcome in our study, alludes to the tendency of B cells to adopt a plasmablast or plasma cell fate. Given the importance of migration between peripheral blood and CNS in MS, it is possible that the tendencies observed in the periphery may be recapitulated in the CNS. In their retrospective study, Rinker et al. ${ }^{8}$ do not distinguish leukocyte categories among the overall increase in intrathecal white blood cells among African American patients with MS over Caucasian counterparts. Thus, in addition to examining the question of intrathecal plasma cell burden, future work with BALAwMS should examine transcriptional mechanisms associated with plasma cell fate. In addition, although intrathecal IgM is associated with a poor MS course, ${ }^{15}$ there is no study to our knowledge that examines whether IgM oligoclonal bands are enriched among BALAwMS relative to other subpopulations. Our finding that frequencies of $\operatorname{IgM}^{+}$ASCs are significantly enhanced in this population warrants such an investigation. However, only class-switched and not $\operatorname{IgM}^{+}$ASC numbers were differentially elevated among subjects with MS, pointing to the likely involvement of class-switch recombination mechanisms alongside ASC differentiation biology. Our work thus facilitates numerous avenues for future study in an effort to better understand and treat aggressive MS.

In this report, we used the term "ethno-ancestry" to both highlight and encapsulate the complexity around societal (ethnicity) and biologic (ancestry) heritage. As with other studies examining the influence of ethno-ancestral categories and MS, we find some value in the use of self-identification according to broad labels to establish study cohorts. However, we recognize that all such labels, whether ethno-ancestry, race, or other variants, ultimately represent combinations of socially constructed institutional and cultural designations. ${ }^{28,29}$ Such categories are ultimately poor reflections of the subtle differences between individuals, ${ }^{30}$ whereas their use may be also confounded by sociohistoric narratives. ${ }^{\text {e15 }}$ Future studies, particularly those seeking to unravel the interplay between ethno-ancestry and disease, should emphasize molecular genetic and epigenetic delineations. In addition to demonstrably transcending broad ancestral categories, underlying molecular genetic factors may be affected by socioeconomic ${ }^{31}$ and behavioral ${ }^{32,33}$ influences important to shaping disease incidence and prognosis.

Ethno-ancestry-based immunologic differences are longestablished observations. $^{34}$ However, these are largely described in immunity and vaccination studies among presumably healthy individuals. ${ }^{35,36}$ For instance, total serum IgG concentrations are more likely elevated among "black" relative to "white" individuals ${ }^{34}$; African American recipients of HIV gp120 vaccination generated significantly greater neutralizing antibody responses compared with whites assessed in a separate study ${ }^{35}$; similarly, according to National Health and Nutritional Examination Survey data, seroprevalence of IgG antibody specific to mumps virus was highest among individuals identifying as "non-Hispanic black" and lowest among "non-Hispanic whites." ${ }^{36}$ Our work is the first to directly demonstrate ethno-ancestry-based immunologic difference in the context of MS. Nonetheless; there are several limitations to our study. These include a cross-sectional design, convenience sample, and the limited resolution provided by broad ethno-ancestral categories. Very few subjects had undergone lumbar puncture procedures as part of standard of care; as such, we were unable to directly relate peripheral differentials with intrathecal antibody burden as reported prior. Despite these limitations, we provide evidence of an ethno-ancestrydependent peripheral blood ASC differential concordant with observations of intrathecal humoral responses.

Over the past 16 years, ${ }^{2,7,37}$ observational studies revealed greater clinical severity and poorer prognosis among individuals of the Black African diaspora, including those identifying within the spectrum of Latin American identity. ${ }^{2,16}$ Both overt and indirect evidence support ethno-ancestry as a critical factor in MS. A primary role for B cells in MS pathogenesis unequivocally shown in $2008^{11,38}$ is not only accentuated in individuals of Black African heritage ${ }^{8}$ but parallels similar ethno-ancestry-based B cell-driven dysregulation in other conditions. ${ }^{39,40}$ For instance, memory B cells from African American patients with systemic lupus erythematosus (SLE) exhibit an activated phenotype relative to Caucasian patients. ${ }^{39}$ Furthermore, plasmablasts are associated with disease activity in SLE. African Americans with SLE exhibit a pronounced plasmablast transcriptomic signature in conjunction with heightened clinical severity relative to Caucasian subjects. ${ }^{40}$ Thus, our results have interdisciplinary implications, as they are consistent with a burgeoning trend of possibly differentially regulated B-cell biology as a nexus through which ethno-ancestry-based disease severity disparities may manifest. ${ }^{39,40}$ Understanding what mediates these differences may be key to unlocking 
major advancements in diagnostics and therapy, both for MS and other maladies.

\section{Acknowledgment}

The authors thank all individuals consenting to participate in this research. They appreciate the members of the Vartanian Lab for critical scientific discourse and logistic support: Drs. Yinghua Ma and Jennifer Linden, Paige Winokur, Samantha Shetty, and Baohua Zhao. They are also appreciative of the physicians, nurses, and staff of the Weill Cornell Multiple Sclerosis Center that helped make this study possible; in particular, Dr. Nancy Nealon for patient recruitment and Stacyann Foster for conducting subject blood draws. Finally, this project was supported by the Mortimer Sackler Neuroregeneration Fund. The authors are also grateful to the Weill Cornell Clinical and Translational Science Center for additional financial provision through NIH/NCATS Grants TL1-TR-002386 and UL1-TR002384-01.

\section{Study funding}

This study was funded by the Mortimer Sackler Neuroregeneration Fund and Weill Cornell Clinical and Translational Science Center NIH/NCATS Grants TL1-TR-002386 and UL1-TR002384-01.

\section{Disclosure}

K.M. Telesford, U.W. Kaunzner, and J. Perumal report no disclosures. S.A. Gauthier has received research grant support from Genzyme and Mallinckrodt in the fiscal year preceding the date of the original submission. X. Wu, I. Diaz, M. KruseHoyer, C. Engel, M. Marcille, and T. Vartanian report no disclosures. Go to Neurology.org/NN for full disclosures.

\section{Publication history}

Received by Neurology: Neuroimmunology \& Neuroinflammation December 13, 2018. Accepted in final form September 5, 2019.

Appendix Authors

\begin{tabular}{|c|c|c|c|}
\hline Name & Location & Role & Contribution \\
\hline $\begin{array}{l}\text { Kiel M. } \\
\text { Telesford, } \\
\text { PhD }\end{array}$ & $\begin{array}{l}\text { Weill } \\
\text { Cornell } \\
\text { Medicine }\end{array}$ & Author & $\begin{array}{l}\text { Designed and conceptualized the } \\
\text { study; analyzed the data; and } \\
\text { drafted the manuscript for } \\
\text { intellectual content }\end{array}$ \\
\hline $\begin{array}{l}\text { Ulrike W. } \\
\text { Kaunzner, } \\
\text { MD, PhD }\end{array}$ & $\begin{array}{l}\text { Weill } \\
\text { Cornell } \\
\text { Medicine }\end{array}$ & Author & $\begin{array}{l}\text { Contributed to project design, } \\
\text { rationale, and patient/subject } \\
\text { recruitment }\end{array}$ \\
\hline $\begin{array}{l}\text { Jai Perumal, } \\
\text { MD }\end{array}$ & $\begin{array}{l}\text { Weill } \\
\text { Cornell } \\
\text { Medicine }\end{array}$ & Author & $\begin{array}{l}\text { Contributed to data acquisition, } \\
\text { data analysis, manuscript writing, } \\
\text { and patient/subject recruitment }\end{array}$ \\
\hline $\begin{array}{l}\text { Susan A. } \\
\text { Gauthier, } \\
\text { DO, MPH }\end{array}$ & $\begin{array}{l}\text { Weill } \\
\text { Cornell } \\
\text { Medicine }\end{array}$ & Author & $\begin{array}{l}\text { Contributed to data acquisition, } \\
\text { study design, and patient/subject } \\
\text { recruitment }\end{array}$ \\
\hline $\begin{array}{l}\text { Xian Wu, } \\
\text { MPH }\end{array}$ & $\begin{array}{l}\text { Weill } \\
\text { Cornell } \\
\text { Medicine }\end{array}$ & Author & $\begin{array}{l}\text { Conducted biostatistical data } \\
\text { analysis, manuscript writing, and } \\
\text { manuscript revision for } \\
\text { intellectual content }\end{array}$ \\
\hline
\end{tabular}

Appendix (continued)

\begin{tabular}{|c|c|c|c|}
\hline Name & Location & Role & Contribution \\
\hline $\begin{array}{l}\text { Ivan Diaz, } \\
\text { PhD }\end{array}$ & $\begin{array}{l}\text { Weill } \\
\text { Cornell } \\
\text { Medicine }\end{array}$ & Author & $\begin{array}{l}\text { Conducted biostatistical data } \\
\text { analysis and manuscript revision } \\
\text { for intellectual content }\end{array}$ \\
\hline $\begin{array}{l}\text { Mason } \\
\text { Kruse- } \\
\text { Hoyer, MD }\end{array}$ & $\begin{array}{l}\text { Weill } \\
\text { Cornell } \\
\text { Medicine }\end{array}$ & Author & $\begin{array}{l}\text { Contributed to data acquisition, } \\
\text { data analysis, patient/subject } \\
\text { recruitment, and manuscript } \\
\text { revision }\end{array}$ \\
\hline $\begin{array}{l}\text { Casey Engel, } \\
\text { BA }\end{array}$ & $\begin{array}{l}\text { Weill } \\
\text { Cornell } \\
\text { Medicine }\end{array}$ & Author & $\begin{array}{l}\text { Contributed to data acquisition, } \\
\text { data analysis, patient/subject } \\
\text { recruitment, and manuscript } \\
\text { revision }\end{array}$ \\
\hline $\begin{array}{l}\text { Melanie } \\
\text { Marcille, BA }\end{array}$ & $\begin{array}{l}\text { Weill } \\
\text { Cornell } \\
\text { Medicine }\end{array}$ & Author & $\begin{array}{l}\text { Contributed to data acquisition, } \\
\text { data analysis, and patient/ } \\
\text { subject recruitment }\end{array}$ \\
\hline $\begin{array}{l}\text { Timothy } \\
\text { Vartanian, } \\
\text { MD, PhD }\end{array}$ & $\begin{array}{l}\text { Weill } \\
\text { Cornell } \\
\text { Medicine }\end{array}$ & Author & $\begin{array}{l}\text { Contributed to study design and } \\
\text { conceptualization, data } \\
\text { interpretation, and manuscript } \\
\text { revision for intellectual content }\end{array}$ \\
\hline
\end{tabular}

\section{References}

1. Cree BAC, Khan O, Bourdette D, et al. Clinical characteristics of African Americans vs Caucasian Americans with multiple sclerosis. Neurology 2004;63:2039-2045.

2. Ventura RE, Antezana AO, Bacon T, Kister I. Hispanic Americans and African Americans with multiple sclerosis have more severe disease course than Caucasian Americans. Mult Scler J 2017;23:1554-1557.

3. Weinstock-Guttman B, Ramanathan M, Hashmi K, et al. Increased tissue damage and lesion volumes in African Americans with multiple sclerosis. Neurology 2010;74: 538-544.

4. Howard J, Battaglini M, Babb JS, et al. MRI correlates of disability in AfricanAmericans with multiple sclerosis. PLoS One 2012;7:e43061.

5. Kimbrough DJ, Sotirchos ES, Wilson JA, et al. Retinal damage and vision loss in African American multiple sclerosis patients. Ann Neurol 2015;77:228-236.

6. Al-Kawaz M, Monohan E, Morris E, et al. Differential impact of multiple sclerosis on cortical and deep gray matter structures in African Americans and Caucasian Americans. J Neuroimaging 2017;27:333-338.

7. Caldito NG, Saidha S, Sotirchos ES, et al. Brain and Retinal Atrophy in AfricanAmericans versus Caucasian-Americans with Multiple Sclerosis: A Longitudinal Study. Brain 2018;141:3115-3129.

8. Rinker JR, Trinkaus K, Naismith RT, Cross AH. Higher IgG index found in African Americans versus Caucasians with multiple sclerosis. Neurology 2007;69:68-72.

9. Seraji-Bozorgzad N, Khan O, Cree BAC, et al. Cerebral gray matter atrophy is associated with the CSF IgG index in African American with multiple sclerosis. J Neuroimaging 2017;65:239.

10. Cepok S, Rosche B, Grummel V, et al. Short-lived plasma blasts are the main B cell effector subset during the course of multiple sclerosis. Brain 2005;128:1667-1676.

11. Hauser SL, Waubant E, Arnold DL, et al. B-cell depletion with rituximab in relapsingremitting multiple sclerosis. N Engl J Med 2008;358:676-688.

12. Eggers EL, Michel BA, Wu H, et al. Clonal relationships of CSF B cells in treatmentnaive multiple sclerosis patients. JCI Insight 2017;2:92724.

13. Elliott C, Lindner M, Arthur A, et al. Functional identification of pathogenic autoantibody responses in patients with multiple sclerosis. Brain 2012;135:1819-1833.

14. Blauth K, Soltys J, Matschulat A, et al. Antibodies produced by clonally expanded plasma cells in multiple sclerosis cerebrospinal fluid cause demyelination of spinal cord explants. Acta Neuropathol 2015;130:765-781.

15. Thangarajh M, Gomez-Rial J, Hedstrom A, et al. Lipid-specific immunoglobulin $\mathrm{M}$ in CSF predicts adverse long-term outcome in multiple sclerosis. Mult Scler J 2008;14: 1208-1213.

16. Khan O, Williams MJ, Amezcua L, Javed A, Larsen KE, Smrtka JM. Multiple sclerosis in US minority populations: clinical practice insights. Neurol Clin Pract 2015;5: 132-142.

17. Kaminski DA, Wei C, Qian Y, Rosenberg AF, Sanz I. Advances in human B cell phenotypic profiling. Front Immunol 2012;3:302.

18. Halliley JL, Tipton CM, Liesveld J, et al. Long-Lived plasma cells are contained within the CD19- CD38hi CD138+ subset in human bone marrow. Immunity 2015;43: 132-145.

19. Krumbholz M, Meinl I, Kümpfel T, Hohlfeld R, Meinl E. Natalizumab disproportionately increases circulating pre-B and B cells in multiple sclerosis. Neurology 2015; 43:132-145.

20. Hauser SL, Bar-Or A, Comi G, et al. Ocrelizumab versus interferon beta-1a in relapsing multiple sclerosis. N Engl J Med 2017;376:221-234. 
21. Baker D, Marta M, Pryce G, Giovannoni G, Schmierer K. Memory B cells are major targets for effective immunotherapy in relapsing multiple sclerosis. EBioMedicine 2017; 16:41-50.

22. Bankoti J, Apeltsin L, Hauser SL, et al. In multiple sclerosis, oligoclonal bands connect to peripheral B-cell responses. Ann Neurol 2014;75:266-276.

23. Palanichamy A, Apeltsin L, Kuo TC, et al. Immunoglobulin class-switched B cells form an active immune axis between CNS and periphery in multiple sclerosis. Sci Translational Med 2014;6:248ra106.

24. Winges KM, Gilden DH, Bennett JL, Yu X, Ritchie AM, Owens GP. Analysis of multiple sclerosis cerebrospinal fluid reveals a continuum of clonally related antibody-secreting cells that are predominantly plasma blasts. J Neuroimmunol 2007;192:226-234.

25. Ligocki AJ, Rivas JR, Rounds WH, et al. A distinct class of antibodies may be an indicator of gray matter autoimmunity in early and established relapsing remitting multiple sclerosis patients. ASN Neuro 2015;7:175909141560961.

26. Cross AH, Stark JL, Lauber J, Ramsbottom MJ, Lyons JA. Rituximab reduces B cells and $\mathrm{T}$ cells in cerebrospinal fluid of multiple sclerosis patients. J Neuroimmunol 2006;180:63-70.

27. Lovato L, Willis SN, Rodig SJ, et al. Related B cell clones populate the meninges and parenchyma of patients with multiple sclerosis. Brain 2011;134:534-541.

28. Foster MW, Sharp RR. Race, ethnicity, and genomics: social classifications as proxies of biological heterogeneity. Genome Res 2002;12:844-850.

29. Collins FS. What we do and don't know about "race," "ethnicity," genetics and health at the dawn of the genome era. Nat Genet 2004;36:S13-S15.

30. Bryc K, Durand EY, Macpherson JM, Reich D, Mountain JL. The genetic ancestry of African Americans, Latinos, and European Americans across the United States. Am J Hum Genet 2015;96:37-53.
31. Marrie RA, Cutter G, Tyry T, Vollmer T, Campagnolo D. Does multiple sclerosisassociated disability differ between races? Neurology 2006;66:1235-1240.

32. McGowan PO, Roth TL. Epigenetic pathways through which experiences become linked with biology. Dev Psychopathol 2015;27:637-648.

33. Saadi A, Himmelstein DU, Woolhandler S, Mejia NI. Racial disparities in neurologic health care access and utilization in the United States. Neurology 2017;88: 2268-2275.

34. Shackelford PG, Granoff DM, Nahm MH, et al. Relation of age, race, and allotype to immunoglobulin subclass concentrations. Pediatr Res 1985;19:846-849.

35. Montefiori DC, Metch B, McElrath MJ, et al. Demographic factors that influence the neutralizing antibody response in recipients of recombinant HIV-1 gp120 vaccines. J Infect Dis 2004;190:1962-1969.

36. Kutty PK, Kruszon Moran DM, Dayan GH, et al. Seroprevalence of antibody to mumps virus in the US population, 1999-2004. J Infect Dis 2010;202:667-674.

37. Kaufman MD, Johnson SK, Moyer D, Bivens J, Norton HJ. Multiple sclerosis severity and progression rate in African Americans compared with whites. Am J Phys Med Rehabil 2003;82:582-590.

38. Bar-Or A, Calabresi PAJ, Arnold D, et al. Rituximab in relapsing-remitting multiple sclerosis: a 72-week, open-label, phase I trial. Ann Neurol 2008;63:395-400.

39. Menard LC, Habte S, Gonsiorek W, et al. B cells from African American lupus patients exhibit an activated phenotype. JCI Insight 2016;1;e87310.

40. Banchereau R, Hong S, Cantarel B, et al. Personalized immunomonitoring uncovers molecular networks that stratify lupus patients. Cell 2016;165:551-565.

References e1-e15 are available at: links.lww.com/NXI/A162. 


\title{
Neurology \\ Neuroimmunology \& Neuroinflammation
}

\author{
Black African and Latino/a identity correlates with increased plasmablasts in MS \\ Kiel M. Telesford, Ulrike W. Kaunzner, Jai Perumal, et al. \\ Neurol Neuroimmunol Neuroinflamm 2020;7; \\ DOI 10.1212/NXI.0000000000000634
}

This information is current as of October 31, 2019

\section{Updated Information \& Services}

References

Subspecialty Collections

Permissions \& Licensing

Reprints including high resolution figures, can be found at: http://nn.neurology.org/content/7/1/e634.full.html

This article cites 40 articles, 2 of which you can access for free at: http://nn.neurology.org/content/7/1/e634.full.html\#\#ref-list-1

This article, along with others on similar topics, appears in the following collection(s):

Autoimmune diseases

http://nn.neurology.org//cgi/collection/autoimmune_diseases

Multiple sclerosis

http://nn.neurology.org//cgi/collection/multiple_sclerosis

Underserved populations

http://nn.neurology.org//cgi/collection/underserved_populations

Information about reproducing this article in parts (figures,tables) or in its entirety can be found online at:

http://nn.neurology.org/misc/about.xhtml\#permissions

Information about ordering reprints can be found online:

http://nn.neurology.org/misc/addir.xhtml\#reprintsus

Neurol Neuroimmunol Neuroinflamm is an official journal of the American Academy of Neurology.

Published since April 2014, it is an open-access, online-only, continuous publication journal. Copyright

Copyright $\odot 2019$ The Author(s). Published by Wolters Kluwer Health, Inc. on behalf of the American

Academy of Neurology.. All rights reserved. Online ISSN: 2332-7812.

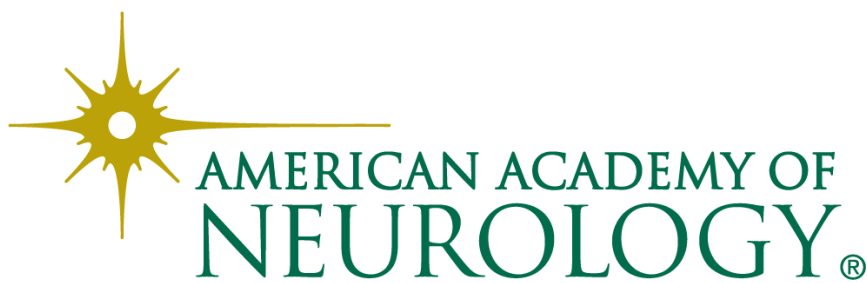

